medRxiv preprint doi: https://doi.org/10.1101/2021.04.15.21255549; this version posted April 20, 2021. The copyright holder for this preprint (which was not certified by peer review) is the author/funder, who has granted medRxiv a license to display the preprint in perpetuity. All rights reserved. No reuse allowed without permission.

\title{
Pharmacokinetics and safety of XAV-19, a swine glyco-humanized polyclonal anti- SARS-CoV-2 antibody, for COVID-19-related moderate pneumonia: a randomized, double-blind, placebo-controlled, phase IIa study
}

Benjamin Gaborit ${ }^{1,2}$, Eric Dailly ${ }^{3}$, Bernard Vanhove ${ }^{4}$, Régis Josien ${ }^{5,6}$, Karine Lacombe ${ }^{7}$, Vincent Dubee $^{8}$, Virginie Ferre ${ }^{2,9}$, Sophie Brouard ${ }^{6}$, Florence Ader ${ }^{10,11}$, Marie-Anne Vibet ${ }^{12}$, Aurélie Le Thuaut $^{12}$, Richard Danger ${ }^{6}$, Laurent Flet $^{13}$, Anne Omnes ${ }^{12}$, Laetitia Berly ${ }^{12}$, Anne Chiffoleau ${ }^{12}$, Alexandra Jobert ${ }^{12}$, Odile Duvaux ${ }^{4}$; François Raffi ${ }^{1,2}$ and POLYCOR trial group*

1. Department of Infectious Disease, Nantes University Hospital, Nantes, France. 2. INSERM CIC1413, Nantes University Hospital and Inserm, Nantes, France. 3. Clinical Pharmacology Department, CHU Nantes, Nantes, France. 4. Xenothera, Nantes, France; 5. Centre de Recherche en Transplantation et Immunologie UMR 1064, INSERM, Université de Nantes, ITUN, CHU Nantes, Nantes, France. 6. Laboratoire d'Immunologie, CIMNA,CHU Nantes, Nantes, France. 7. Institut Pierre Louis d'Epidémiologie et de Santé Publique, Sorbonne Université, INSERM, AP-HP, Hôpital Saint-Antoine, Service des Maladies Infectieuses et Tropicales, Paris, France 8. Service de Maladies Infectieuses et Tropicales, Centre Hospitalier Universitaire d'Angers, Angers 9.Virology Laboratory University Hospital, Nantes France 10. Centre International de Recherche en Infectiologie (CIRI), Inserm 1111, Université Claude Bernard Lyon 1, CNRS, UMR5308, Ecole Normale Supérieure de Lyon, Université Lyon, F-69007 Lyon, France 14. Département des Maladies infectieuses et tropicales, Hospices Civils de Lyon, F69004 Lyon, France 12. CHU Nantes, Sponsor Department, Nantes, France. 13. CHU Nantes, Pharmacy Department, Nantes, France.

* Trial group members are listed at the end of the manuscript

Corresponding author: Benjamin Gaborit, Infectious Diseases Department, Hôtel-Dieu University Hospital, 1 Place Alexis-Ricordeau, 44000 Nantes, France Tel.: +33 240083351 Fax: +33 240083335 E-mail: benjamin.gaborit@chu-nantes.fr

Alternate corresponding author: François Raffi, Infectious Diseases Department, Hôtel-Dieu University Hospital, 1 Place Alexis-Ricordeau, 44000 Nantes, France Tel.: 33240083372 Fax: +33(0) 240083315 E-mail: francois.raffi@,chu-nantes.fr

Running title: Polyclonal humanized antibody in COVID19

Main point: In this first-in-human trial including patients with COVID-19-related pneumonia, a single $2 \mathrm{mg} / \mathrm{kg}$ dose of a swine glyco-humanized polyclonal anti-SARS-CoV-2 antibody, achieved serum concentrations above the target of neutralization threshold for 8 days in all patients, with good tolerability and safety.

Keywords: pneumonia, COVID-19, Phase IIa, polyclonal glyco-humanized anti-SARS-CoV-2 NOTE: This preprint reports new research that has not been certified by peer review and should not be used to guide clinical practice. antibody, XAV-19 
medRxiv preprint doi: https://doi.org/10.1101/2021.04.15.21255549; this version posted April 20, 2021. The copyright holder for this preprint (which was not certified by peer review) is the author/funder, who has granted medRxiv a license to display the preprint in perpetuity. All rights reserved. No reuse allowed without permission.

\begin{abstract}
Background: We assessed the pharmacokinetics and safety of XAV-19, a swine glyco-humanized polyclonal antibody against SARS-CoV-2, in COVID-19-related moderate pneumonia. In vitro, 100\% neutralization activity is seen with XAV-19 concentrations above $5 \mu \mathrm{g} / \mathrm{mL}$.
\end{abstract}

Methods: In this phase 2a trial, adults with COVID-19-related moderate pneumonia of $\leq 10$ days duration were randomized to infusion of XAV-19 $0.5 \mathrm{mg} / \mathrm{kg}$ at day 1 and day 5 (group 1), $2 \mathrm{mg} / \mathrm{kg}$ at day 1 and day 5 (group 2), $2 \mathrm{mg} / \mathrm{kg}$ at day 1 (group 3) or placebo.

Results: Eighteen patients ( $\mathrm{n}=7$ for group $1, \mathrm{n}=1$ for group 2, $\mathrm{n}=5$ for group 3, and $\mathrm{n}=5$ for placebo) were enrolled. Baseline characteristics were similar across groups, XAV-19 serum concentrations $\left(\mu \mathrm{g} / \mathrm{mL}\right.$, median, range) at $\mathrm{C}_{\max }$ and at day 8 were 9.1 (5.2-18.1) and 6.4 (2.8-11.9), 71.5 and 47.2, and $50.4(29.1-55.0)$ and $20.3(12.0-22.7)$ for groups 1,2 and 3 , respectively $(\mathrm{p}=0.012)$. Terminal half-life (median, range) was estimated at $11.4(5.5-13.9)$ days for $2 \mathrm{mg} / \mathrm{kg}$ of XAV-19 at day 1. Serum XAV19 concentrations were above the target concentration of $10 \mu \mathrm{g} / \mathrm{mL}$ (tow fold the in vitro $100 \%$ inhibitory concentration $\left[\mathrm{IC}_{100}\right]$ ) from the end of perfusion to more than 8 days for XAV-19 $2 \mathrm{mg} / \mathrm{kg}$ at day 1 . No hypersensitivity or infusion-related reactions were reported during treatment, there was no discontinuation for adverse events and no serious adverse events related to study drug.

Conclusions: Single intravenous dose of $2 \mathrm{mg} / \mathrm{kg}$ of XAV-19 demonstrated high serum concentrations, predictive of potent durable neutralizing activity with good tolerability.

Trial registration: ClinicalTrials.gov Identifier: NCT04453384 
medRxiv preprint doi: https://doi.org/10.1101/2021.04.15.21255549; this version posted April 20, 2021. The copyright holder for this preprint

(which was not certified by peer review) is the author/funder, who has granted medRxiv a license to display the preprint in perpetuity.

All rights reserved. No reuse allowed without permission.

\section{INTRODUCTION}

Since the first identification of severe acute respiratory syndrome coronavirus 2 (SARS-CoV-2) from patients with bilateral pneumonia, in Wuhan, China, during December 2019, the ongoing pandemic of coronavirus disease 2019 (COVID-19) has affected more than 127 Million people and caused death in 2.8 Million [1,2]. Among patients hospitalised for COVID-19, 15-20\% develop a severe respiratory failure requiring admission to intensive care unit [3]. Corticosteroids and anticoagulant therapy have improved prognosis of patients requiring respiratory support for severe or critical pneumonia $[4,5]$. Multitargeted interventions in severe COVID-19, combining potent antiviral(s), steroids, anticoagulants and in most severe cases adjunctive immune-based therapy such as tocilizumab, could constitute an optimized cocktail to halt further progress to respiratory failure, acute respiratory distress syndrome (ARDS), multi-organ dysfunction, and death [6-8].

In an ongoing trial, we are investigating XAV-19, a swine glyco-humanized polyclonal SARS-CoV-2neutralizing antibody [9], in hospitalized patients with COVID-19 pneumonia requiring low flow oxygen supplementation [10]. The main hypothesis is that reducing viral burden and improving specific immunity by passive antibodies administration at hospital entry of patients hospitalized for COVID-19related moderate pneumonia within 10 days of first symptom onset could lead to clinical benefit. Animal-derived heterologous polyclonal antibodies, used as a passive heterologous immunotherapy, could represent a highly efficient alternative to the use of monoclonal antibodies in COVID-19 by targeting multiple antigen epitopes. The dose rationale for the administration of XAV-19 was based on assessment of in vitro inhibitory potency of XAV-19 on SARS-CoV-2 virus and the target serum concentration was established at $10 \mu \mathrm{g} / \mathrm{mL}[9,11]$.

Here, we report results of the first part of this ongoing clinical trial involving patients hospitalized for COVID-19-related moderate pneumonia requiring oxygen supplementation. In this phase IIa of the trial, objectives of this first-in-human administration of XAV-19 were to assess its pharmacokinetics and safety.

\section{METHODS}

Study design and participants 
medRxiv preprint doi: https://doi.org/10.1101/2021.04.15.21255549; this version posted April 20, 2021. The copyright holder for this preprint (which was not certified by peer review) is the author/funder, who has granted medRxiv a license to display the preprint in perpetuity. All rights reserved. No reuse allowed without permission.

This is an ongoing multicenter, randomized, double-blind, placebo-controlled, phase IIa-III clinical trial involving hospitalized patients with COVID-19-related moderate pneumonia requiring low-flow oxygen supplementation[10]. The first part was conducted as a phase IIa, first-in-human dose-ranging study at four sites in France, to assess the pharmacokinetics and safety of XAV-19, to select the optimal dose for the second part of the trial, designed as a phase III for which recruitment is ongoing. This study was conducted in accordance with good clinical practice procedures, all applicable regulatory requirements, and the guiding principles of the Declaration of Helsinki. The study protocol was reviewed and approved by the Ethics Committee OUEST VI (20.06.15.31306). All patients provided written informed consent before the entry in the study. The study is registered with ClinicalTrial.gov, NCT04453384.

We prospectively identified hospitalized adults aged between 18 and 85 years, with SARS-CoV-2 infection confirmed by a positive RT-PCR and onset of first symptoms less than 10 days prior to enrolment. Inclusion criteria included COVID-19-related moderate pneumonia defined by $\mathrm{SpO} 2 \geq 92 \%$ on oxygen supplementation $\leq 6 \mathrm{~L} / \mathrm{min}$ by low-flow nasal cannula or mask (score of 4 on the World Health Organization 7-point Clinical Progression Scale (WHO-CPS)) and evidence of pulmonary involvement on lung examination (rales/crackles) and/or chest-imaging (Chest X-ray or computed tomography). Exclusion criteria were evidence of multiorgan failure, receipt of immunoglobulins or any blood products in the past 30 days, psychiatric or cognitive illness or recreational drug/alcohol use that would affect subject safety or compliance, end-stage renal disease (eGFR $<15 \mathrm{~mL} / \mathrm{min} / 1,73 \mathrm{~m}^{2}$ ), childPugh C-stage liver cirrhosis, decompensated cardiac insufficiency, known allergy, hypersensitivity or intolerance to the study drug or to any of its components, life expectancy estimated to be less than 6 months patient under guardianship or trusteeship, pregnancy or lack of effective contraception in women of childbearing potential.

\section{Randomization and masking}

Eligible participants were assigned to two consecutive groups of approximately eight patients per cohort of ascending dose, in a 1:1 randomization scheme per dose for the first two patients and a five active and one placebo randomization scheme per dose for the six following participants of each cohort. The two doses of XAV-19 were $0.5 \mathrm{mg} / \mathrm{kg}$ and $2 \mathrm{mg} / \mathrm{kg}$ administered over one hour intravenous infusion at 
medRxiv preprint doi: https://doi.org/10.1101/2021.04.15.21255549; this version posted April 20, 2021. The copyright holder for this preprint

(which was not certified by peer review) is the author/funder, who has granted medRxiv a license to display the preprint in perpetuity.

All rights reserved. No reuse allowed without permission.

days 1 and 5. After inclusion of the first two participants in each cohort, the safety and tolerability of the treatment was assessed up to 8 days post-infusion by an independent data monitoring committee before continuation of enrolment. Following blinded analysis of the first cohort $(0.5 \mathrm{mg} / \mathrm{kg}$ at D1 and D5) and of the first two patients (one active and one placebo) of the second cohort ( $2 \mathrm{mg} / \mathrm{kg}$ at D1 and D5), the remaining patients of the second cohort received a single infusion of $2 \mathrm{mg} / \mathrm{kg}$ of XAV-19 at day 1. All patients also received therapy for COVID-19 according to standard of care (SOC) in the participating centres. This SOC included use of dexamethasone and other treatments per local practice and national guidelines at time of the study, which may include, not exclusively, antibiotics, antiviral treatment, immune therapies not based on antibodies administration and anticoagulants. Simple randomization was done using web-based simple (unstratified) allocation by trained clinical research staff. Study investigators, all research and analysis teams, and patients were masked to treatment allocation. The study medications were prepared and dispensed by the hospital pharmacy and presented as ready-to-use aqueous solutions in prelabelled infusion kits according to regulatory requirements. The study medication was then administered to the patients by the medical ward' nurses, upon receipt.

\section{Procedures}

Medical history and demographic data were collected at screening. Before dosing, patients underwent evaluation of vital signs, physical examination, assessments for pneumonia, blood haematology and chemistry as well as nasopharyngeal swab for SARS-CoV-2 RT-PCR. Patients also had a 12-lead electrocardiogram, and if clinically required chest x-rays and/or CT scan.

During and for the 2 hours after study treatment infusion, vital signs (temperature, respiratory rate, heart rate, systolic and diastolic blood pressures, and oxygen saturation) were monitored every 30 minutes, and particular attention was paid to occurrence of hypersensitivity or infusion-related reactions. Patients were followed for 2 months after the first infusion, with clinical assessment, including respiratory status and 7-point ordinal scale, daily during hospitalization, at days 8, 15, 29 and 60. Blood haematology and chemistry were collected at each visit. Samples to measure drug serum concentrations were collected in all patients at days 1 (pre-dose, post-dose), 3, 5 (pre-dose and post-dose, if appropriate), 8, 15, and 29. Drug concentration was assessed at Charles River Laboratories, Evreux, France, with a validated swine IgG-specific sandwich ELISA, presenting a lower limit of quantification of approximately $50 \mathrm{ng} / \mathrm{mL}$ in 
medRxiv preprint doi: https://doi.org/10.1101/2021.04.15.21255549; this version posted April 20, 2021. The copyright holder for this preprint

(which was not certified by peer review) is the author/funder, who has granted medRxiv a license to display the preprint in perpetuity.

All rights reserved. No reuse allowed without permission.

human serum. The use of concomitant medications was recorded throughout the study. Patients were also regularly assessed for adverse events and possible relation to the investigational medicinal product.

\section{Outcomes}

The two primary outcomes were the pharmacokinetic measurement of the serum concentration of XAV19 at day 8 and tolerability over 29 days, comparing the XAV-19 treated participants and placebo group. Pharmacokinetic parameters of XAV-19 that were evaluated were serum drug concentrations determined immediately at the end of infusion, maximum serum concentration $\left(\mathrm{C}_{\max }\right)$; time to maximum serum concentration $\left(T_{\max }\right)$; area under the serum concentration-time curve extrapolated to infinity $(\mathrm{AUC0}-\infty)$, which was calculated using the formula $\mathrm{AUC}_{0-\text { day }} 29$ (area under the serum concentration-time curve measured to the concentration at day 29 using the trapezoidal rule) and serum concentration at day $29 / \mathrm{Ke}$ (Ke is the apparent first-order terminal rate constant calculated from a semi-log plot of the serum concentration versus time curve); terminal half-life $\left(\mathrm{t}_{1 / 2}\right)$ as determined by quotient $0.693 / \mathrm{Ke}$; clearance, as determined by quotient dose/AUC0- $\infty$; and volume of distribution, as determined by quotient clerarance/Ke.

Safety parameters were evaluated over 29 days by the onset of all adverse events suspected to be related to XAV-19 and incidence of serious adverse events, of treatment-related adverse events leading to discontinuation of study drug, of hypersensitivity reactions and infusion-related reactions.

Secondary and additional outcomes included pharmacokinetics of XAV-19 up to day 29 and clinical outcome (ICU transfer, 7-point ordinal scale, length of hospital stay). In an exploratory analysis, SARSCoV-2 nasopharyngeal viral loads changes were assessed in an exploratory sub-cohort of patients treated by XAV-19 in comparison to the placebo group. Nasopharyngeal swabs were collected in $3 \mathrm{~mL}$ of viral transport medium (Yocon, China). RNA extraction was done with EZ1 DSP virus kit (EZ1,Qiagen) according to manufacturer's instructions. Viral nucleic acids were detected using a multiplex SARSCoV-2 RT-qPCR, using RdRp-IP2 and RDRP IP4 adapted from Charite Protocol and National Reference Centre for Respiratory Viruses Institute Pasteur [12,13] When a sample was positive, quantification of the number of RNA copies was done by RT-qPCR using a specific in vitro transcribed RNA, according to a scale ranging from 2.2 to $10 \log _{10} \mathrm{c} / \mathrm{mL}$. 
medRxiv preprint doi: https://doi.org/10.1101/2021.04.15.21255549; this version posted April 20, 2021. The copyright holder for this preprint (which was not certified by peer review) is the author/funder, who has granted medRxiv a license to display the preprint in perpetuity. All rights reserved. No reuse allowed without permission.

\section{Statistical analysis}

The safety population included all subjects randomized into the study who received at least one dose of study drug. The intent-to-treat exposed (ITT-E) population was defined as all subjects who met study criteria and were randomized into the study with documented evidence of having received at least one dose of randomized treatment and at least one post-baseline measurement of serum XAV-19 titers. The per-protocol population was defined as all subjects included in the ITT-E population excluding those who had at least one major protocol deviation. Placebo patients were pooled for the purpose of analysis.

The PK concentration population included all subjects who completed the study drug schedule. Categorical variables were summarized by percent and comparisons were assessed using an exact Fisher test. Continuous variables were summarized by means and standard error, and medians and interquartile range, comparisons between groups were done using a Kruskal-Wallis test. The primary endpoint was evaluated for ITT-E population by a Kruskal-Wallis test between placebo patients and treated patients. The number of adverse events was compared between groups of patients using an exact Fisher test. Comparisons of pharmacokinetic parameters were conducted using Kruskal-Wallis test. The relationship between AUC0- $\infty$ and cumulative administered dose of XAV 19 was explored by a linear regression model. Groups of treatment were described according to variables in of the secondary endpoints. A p-value $<0.05$ was defined as significant.

\section{RESULTS}

Between Aug 30 $0^{\text {th }}, 2020$ and Dec $7^{\text {th }}, 2020,18$ patients with COVID-19-related moderate pneumonia were randomized, one withdrew consent before day 5 second infusion (cohort 1) and 17 completed all study visits (Supplemental Figure 1). Hence the safety population is constituted of 18 patients, whereas the ITT-E population was constituted of 17 patients. Demographics and baseline characteristics of the 17 patients were similar across groups (Table 1). Of the 17 analyzed patients, 12 were treated with XAV-19 (0.5 mg/kg at days 1 and $5 \mathrm{n}=6,2 \mathrm{mg} / \mathrm{kg}$ at days 1 and $5 \mathrm{n}=1,2 \mathrm{mg} / \mathrm{kg}$ at day $1 \mathrm{n}=5)$ and five with placebo, 11 were males (64.7\%), median age was 71 years [interquartile range (IQR) 51-75], and median body mass index (BMI) was $27.4[25.3-31.2] \mathrm{kg} / \mathrm{m}^{2}$. The majority $(14 / 17)$ of patients had at least one comorbidity, including three with immunodeficiency disease (Table 1). At screening, all 
medRxiv preprint doi: https://doi.org/10.1101/2021.04.15.21255549; this version posted April 20, 2021. The copyright holder for this preprint (which was not certified by peer review) is the author/funder, who has granted medRxiv a license to display the preprint in perpetuity. All rights reserved. No reuse allowed without permission.

patients were hospitalized, requiring supplemental oxygen by nasal prongs or mask with low oxygen delivery (WHO scale 4). Associated COVID-19 therapies were steroids in all patients and remdesivir in $8(47 \%)$ patients. The median time from symptom onset to the initial infusion of investigational drug was 8 days [IQR 6-9].

Pharmacokinetic parameters of XAV-19 are presented in Table 2. XAV-19 serum concentrations (median [range]) at day 8 were $6.4 \mu \mathrm{g} / \mathrm{mL}$ [2.8-11.9] in patients who received $0.5 \mathrm{mg} / \mathrm{kg}$ of XAV-19 at days 1 and 5, $20.3 \mu \mathrm{g} / \mathrm{mL}(12.0-22.7)$ for those who received $2 \mathrm{mg} / \mathrm{kg}$ at day $1,47.2$ for for the one who received $2 \mathrm{mg} / \mathrm{kg}$ at days 1 and 5 ( $\mathrm{p}=0.012$ between groups) (Table 2). Serum concentrations were above $29 \mu \mathrm{g} / \mathrm{mL}$ in all patients at day 1 post-infusion of $2 \mathrm{mg} / \mathrm{kg}$ of XAV-19 (Table 2). Based on a target neutralization threshold of $10 \mu \mathrm{g} / \mathrm{mL}$ of XAV-19, all patients treated with $2 \mathrm{mg} / \mathrm{kg}$ ( 1 or 2 infusions) had serum concentrations above the target at day 8. A proportional relationship between cumulative administered dose and AUC0- $\infty$ was found suggesting a linear pharmacokinetic for XAV-19 between these doses (Figure 1). According to this linearity, no significant difference between $t_{1 / 2}$ values was observed between the groups of patients. The half-life [median; range; $\mathrm{n}=12$ ] for all XAV-19 doses was $13 \cdot 0(0.7-19.4)$ days, which allowed to maintain serum concentration of XAV-19 above the previously defined target serum level of $10 \mu \mathrm{g} / \mathrm{mL}$ (two fold the $100 \%$ neutralization activity in vitro) during 15 days after a single $2 \mathrm{mg} / \mathrm{kg}$ administration for most patients (Figure 2) [9]. After a single infusion of the $2 \mathrm{mg} / \mathrm{kg}$ dose, the volume of distribution (L) and the clearance (L/h) (median; range; $\mathrm{n}=5$ ) were respectively $4.9(4.0-8.7)$ and $0.015(0.010-0.021)$.

A summary of the adverse events is presented in Table 3. XAV-19 was well tolerated, with no differences in adverse events nature and rate between placebo and XAV-19 group and no serious adverse events related to the study drug. Only two patients experienced drug-related grade 1 adverse event (one had lymphadenopathy in the placebo group, one had localized transient ecchymotic rash at day 15 in the $0.5 \mathrm{mg} / \mathrm{kg}$ group). Severe adverse events occurred in three patients in the placebo group with two grade 3 events (worsening asthenia and increased dyspnoea) and one grade 4 event (respiratory distress), and in five patients in the XAV-19 group with two grade 4 events (worsening respiratory distress) and three grade 3 events (respiratory failure and two hepatobiliary disorders) (Supplemental Tables 1 and 2). No hypersensitivity or infusion-related reactions were reported during treatment, and there were no 
medRxiv preprint doi: https://doi.org/10.1101/2021.04.15.21255549; this version posted April 20, 2021. The copyright holder for this preprint

(which was not certified by peer review) is the author/funder, who has granted medRxiv a license to display the preprint in perpetuity.

All rights reserved. No reuse allowed without permission.

treatment discontinuations due to adverse events. There were no consistent or clinically significant changes in haematology, clinical chemistry, vital signs, or urinalysis values. Of the 17 patients included in the ITT-E population, three (17.6\%) developed respiratory failure requiring high flow ventilation, one $(20 \%)$ in the placebo group and two (16.6\%) in patients who received XAV-19. At day $8,11 / 17$ patients were free of oxygen, $3 / 5$ in the placebo group and 8/12 in the XAV-19 group. At last follow-up visit, on day 60 , one patient had died at day 58 , from complications of comorbidities in the $0.5 \mathrm{mg} / \mathrm{kg}$ group and all other patients showed clinical improvement and had been discharged from the hospital (Figure 3). Longitudinal assessment of quantitative viral load in nasopharyngeal swab was available in four patients in the $2 \mathrm{~m} / \mathrm{kg} \mathrm{XAV-19}$ groups and in five patients in the placebo group, suggesting a trend to faster clearance of SARS-CoV-2 with XAV-19 (Figure 4).

\section{DISCUSSION}

This study was a randomized, double-blind, placebo-controlled, multicentre, phase IIa trial evaluating the optimal dose and the safety of XAV-19, a swine-derived glyco-humanized polyclonal SARS-CoV2- neutralizing antibody, in patients admitted to hospital with COVID-19-related moderate pneumonia. The results of this first-in-human trial have shown that a single infusion of XAV-19 at $2 \mathrm{mg} / \mathrm{kg}$ maintained serum concentration of XAV19 well above the predicted neutralization target concentration of $10 \mu \mathrm{g} / \mathrm{mL}$ during at least 8 days post-infusion [9]. The median elimination half-life for XAV-19 2 $\mathrm{mg} / \mathrm{kg}$ was estimated at 11.4 days, which provides rationale for a single infusion to maintain in vivo neutralizing activity for at least 8 days. Our data also suggest that XAV-19 might enhance viral clearance, even in patients admitted to hospital after on average one week of onset of SARS-CoV-2 symptoms, although our analysis was exploratory and performed on a limited number of patients. Studies have shown that symptom onset is not a sufficient predictor of level of viral load in respiratory secretions, as high viral loads might persist for 2 weeks, nor of individual innate immune response or ability of this immune response to control ongoing viral replication[14-16]. Then, although maximal benefit of any antiviral therapy, either specific antiviral or neutralizing antibodies, is expected when treatment is started earlier in the illness, benefit could also persist in patients treated with longer duration of symptoms, as demonstrated with remdesevir[6]. 
medRxiv preprint doi: https://doi.org/10.1101/2021.04.15.21255549; this version posted April 20, 2021. The copyright holder for this preprint

(which was not certified by peer review) is the author/funder, who has granted medRxiv a license to display the preprint in perpetuity.

All rights reserved. No reuse allowed without permission.

XAV-19 maintains neutralization activity against the most predominant SARS-CoV-2 variants, including the initial Wuhan strain and the 501Y.V1 and 501Y.V2 variants, while some anti-SARS-CoV2 monoclonal antibodies exhibit reduced activity against the new variants[11]. Indeed, bamlanivimab has slight loss of activity against the B.1.1.7 variant, while both bamlanivimab and etesivimab have complete loss of activity against the B.1.351 variant.; casivirimab has large loss of activity against the B.1.351 variant and imdevimab retains similar activity against all strains. Interim results of recent trials have suggested that among non-hospitalized patients with mild to moderate COVID-19 illness not requiring oxygen supplementation, treatment with a combination of 2 anti-spike neutralizing monoclonal antibodies was associated with antiviral effect. To what extent such effect translates in clinical benefit by reducing worsening and requirement for hospitalization is being assessed in phase III trials, especially in high-risk patients[17-19]. As new strains of SARS-CoV-2 of epidemiological importance might continue to emerge, it will be necessary to carefully determine both in vitro and in vivo the neutralizing activity of cocktails of monoclonal antibodies and of XAV-19. Polyclonal antibodies offer the advantages over monoclonal antibodies to cover the different epitopes of the target antigen and to mimic natural responses to the antigen, with in addition a lower cost.

XAV-19 was well tolerated and no major safety issues or dose-related trends were identified. The clinical outcome of COVID-19 was not different in both groups, but numbers were too small in this phase IIa study to see any trend. Rate of worsening of respiratory failure, based on WHO scale, was within expected range based on characteristics of enrolled population, and the death observed at day 59 was unrelated to study drug or COVID-19 [20,21]. No immediate hypersensitivity reactions or infusionrelated reactions were reported in our study contrasting to reports and warning with cocktail of antispike monoclonal antibodies [19].

An important limitation of this phase IIa portion of our trial is the small sample size, that did not allow to determine if XAV-19 was associated with improved outcomes. This question will be rigorously tested in the analysis of the phase III part of this ongoing trial. Even if the number of patients who received XAV-19 was low, there were no safety concerns. Second, higher doses of XAV-19 were not explored. However, the $2 \mathrm{mg} / \mathrm{kg}$ dose achieved sustained active concentrations. 
medRxiv preprint doi: https://doi.org/10.1101/2021.04.15.21255549; this version posted April 20, 2021. The copyright holder for this preprint

(which was not certified by peer review) is the author/funder, who has granted medRxiv a license to display the preprint in perpetuity.

All rights reserved. No reuse allowed without permission.

In conclusion, XAV-19 was well tolerated in patients admitted to hospital for COVID-related moderate pneumonia requiring low-flow oxygen supplementation. The pharmacokinetic results of a single infusion of $2 \mathrm{mg} / \mathrm{kg}$ suggest that this dose has the potential to successfully block viral diffusion in humans and supports the selection of this regimen for the ongoing multicentre randomized (1:1), doubleblind, placebo-controlled phase III trial (ClinicalTrial.gov, NCT04453384) involving 400 patients.

\section{Authors' contributions}

BG and FR conceptualised the study. BG, BV, RJ, SB, OD, AO, BL, OD, and FR were involved in finalizing the protocol of the study. BG, FR, LB, and AO supervised the study. BG, KL, VD, FA and FR were involved in the clinical care of the patients. AC, AJ, LB were involved in data curation. ED, $\mathrm{BV}, \mathrm{VF}$ MAV, RJ, SB, RD, ALT, AC and AJ did formal analysis of data. LF was responsible of central depository and distribution of study drugs. BG and FR prepared the original draft of the manuscript. All authors were involved in writing, reviewing, and editing of the manuscript.

\section{Declaration of interests}

BG reports receipt non-financial support from Gilead Sciences and MSD, outside of the submitted work. $\mathrm{BV}$ is an employee and chief scientific officer/operating officer of Xenothera, and own shares and holds share options in Xenothera.

KL reports receipt of personal fees from and non-financial support from Abbvie, Chiesi, Healthcare, Janssen, MSD and ViiV outside of the submitted work.

VD reports receipt non-financial support from Gilead Sciences, MSD and Sanofi-Pasteur, outside of the submitted work.

OD is a cofounder of Xenothera, is the CEO of Xenothera and own shares and holds share options in Xenothera.

FR reports receipt of personal fees from Abbvie, Gilead Sciences, Janssen, MSD and ViiV Healthcare, outside of the submitted work.

All other authors report no conflict of interest. 
medRxiv preprint doi: https://doi.org/10.1101/2021.04.15.21255549; this version posted April 20, 2021. The copyright holder for this preprint

(which was not certified by peer review) is the author/funder, who has granted medRxiv a license to display the preprint in perpetuity.

All rights reserved. No reuse allowed without permission.

\section{Data sharing}

The data analysed and presented in this study are available from the corresponding author on reasonable request, providing the request meets local ethical and research governance criteria after publication. Data collected during the study may be processed electronically, in accordance with the requirements of the CNIL (compliance with reference methodology MR001). The study protocol is provided in the appendix.

Funding: This work was funded by Nantes University Hospital Research Department with support from Public Investment Bank (BPI France) in the framework of the "Investment for the Future" programme (Programme d'Investissements d'Avenir ) and Xenothera. The funder of the study had a role in study design, data collection, data analysis. The corresponding author and co-authors interpreted the data, wrote the report had full access to all the data in the study and had final responsibility for the decision to submit for publication.

\section{Acknowledgements}

We thank clinical and research teams, as well as pharmacists and virologists at all the participating clinical centres, who contributed to the management of the study patients for their commitment to providing optimal patient care.

\section{*POLYCOR study group}

Trial development team: Laetitia Berly, Sophie Brouard, Odile Duvaux, Laurent Flet, Benjamin Gaborit, Régis Josien, Alexandra Jobert, Aurélie Le Thuaut, Anne Omnès, François Raffi, Emilie Rebouilleau, Laurent Vacher, Bernard Vanhove, Marie-Anne Vibet.

Trial management team: Anne Chiffoleau, Laetitia Berly, Benjamin Gaborit, Marion Gautier, François Raffi, Joseph Herault, Alexandra Jobert, Aurélie Le Thuaut, Anne Omnès, Ludivine Perrier, Emily Rebouilleau, Sandrine Renaud, Marie-Anne Vibet.

Trial Steering Comité: Florence Ader, Odile Duvaux, Virginie Ferre, Benjamin Gaborit, Karine Lacombe, Anne Omnès, François Raffi, Bernard Vanhove, Eric Vicaut 
medRxiv preprint doi: https://doi.org/10.1101/2021.04.15.21255549; this version posted April 20, 2021. The copyright holder for this preprint

(which was not certified by peer review) is the author/funder, who has granted medRxiv a license to display the preprint in perpetuity.

All rights reserved. No reuse allowed without permission.

Trial Independent data monitoring committee: Bruno Hoen, Laura Richert, Caroline Solas, Astrid

Vabret

Investigators: Angers : Marc-Antoine Custaud, Valérie Daniel, Vincent Dubee, Rafaël Mahieu ;

Nantes : Cécile Braudeau, Marie Chauveau, Eric Dailly, Colin Deschanvres, Laurent Flet, Benjamin

Gaborit, Matthieu Gregoire, Anne-sophie Lecomte, Maëva Lefebvre, Pascale Morineau Le Houssine,

François Raffi, Martine Tching-Sin. ; Lyon : Florence Ader, Agathe Becker, Pierre Chauvelot, Anne

Conrad, Tristan Ferry, Julianne Oddone, Thomas Perpoint, Cécile Pouderoux, Sandrine Roux, Claire

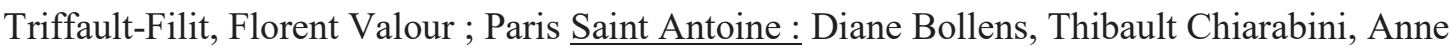

Daguenel-Nguyen, Emmanuelle Gras, Patrick Ingiliz, Karine Lacombe, Bénédicte Lefebvre, Laura

Levi, Zineb Ouazene, Jérôme Pacanowski, Laure Surgers, Nadia Valin.

\section{REFERENCES}

1. Zhu N, Zhang D, Wang W, et al. A Novel Coronavirus from Patients with Pneumonia in China, 2019. N Engl J Med 2020; 382:727-733.

2. COVID-19 Map. Available at: https://coronavirus.jhu.edu/map.html. Accessed 5 April 2021.

3. Wu Z, McGoogan JM. Characteristics of and Important Lessons From the Coronavirus Disease 2019 (COVID-19) Outbreak in China: Summary of a Report of 72314 Cases From the Chinese Center for Disease Control and Prevention. JAMA 2020;

4. INSPIRATION Investigators, Sadeghipour P, Talasaz AH, et al. Effect of Intermediate-Dose vs Standard-Dose Prophylactic Anticoagulation on Thrombotic Events, Extracorporeal Membrane Oxygenation Treatment, or Mortality Among Patients With COVID-19 Admitted to the Intensive Care Unit: The INSPIRATION Randomized Clinical Trial. JAMA 2021;

5. RECOVERY Collaborative Group, Horby P, Lim WS, et al. Dexamethasone in Hospitalized Patients with Covid-19. N Engl J Med 2021; 384:693-704.

6. Beigel JH, Tomashek KM, Dodd LE, et al. Remdesivir for the Treatment of Covid-19 - Final Report. N Engl J Med 2020; 383:1813-1826.

7. Wölfel R, Corman VM, Guggemos W, et al. Virological assessment of hospitalized patients with COVID-2019. Nature 2020; 581:465-469.

8. Gaborit B, Bergmann J, Mussini C, et al. Plea for multitargeted interventions for severe COVID19. Lancet Infect Dis 2020; 20:1122-1123.

9. Vanhove B, Duvaux O, Rousse J, et al. High neutralizing potency of swine glyco-humanized polyclonal antibodies against SARS-CoV-2. Eur J Immunol 2021 Feb

12:10.1002/eji.202049072. Online ahead of print. 
medRxiv preprint doi: https://doi.org/10.1101/2021.04.15.21255549; this version posted April 20, 2021. The copyright holder for this preprint

(which was not certified by peer review) is the author/funder, who has granted medRxiv a license to display the preprint in perpetuity.

All rights reserved. No reuse allowed without permission.

10. Gaborit B, Vanhove B, Vibet M-A, et al. Evaluation of the safety and efficacy of XAV-19 in patients with COVID-19-induced moderate pneumonia: study protocol for a randomized, double-blinded, placebo-controlled phase 2 (IIa and 2b) trial. Trials 2021; 22:199.

11. Vanhove B, Marot SS, Gaborit B, et al. XAV-19, a novel swine glyco-humanized polyclonal antibody against SARS-CoV-2 spike, efficiently neutralizes B.1.1.7 British and B.1.351 SouthAfrican variants. bioRxiv 2021; :2021.04.02.437747.

12. Corman VM, Landt O, Kaiser M, et al. Detection of 2019 novel coronavirus (2019-nCoV) by real-time RT-PCR. Euro Surveill 2020; 25.

13. Lescure F-X, Bouadma L, Nguyen D, et al. Clinical and virological data of the first cases of COVID-19 in Europe: a case series. Lancet Infect Dis 2020; 20:697-706.

14. Gutiérrez-Gutiérrez B, del Toro MD, Borobia AM, et al. Identification and validation of clinical phenotypes with prognostic implications in patients admitted to hospital with COVID-19: a multicentre cohort study. The Lancet Infectious Diseases 2021; Available at: https://www.sciencedirect.com/science/article/pii/S1473309921000190. Accessed 5 April 2021.

15. Szabo PA, Dogra P, Gray JI, et al. Longitudinal profiling of respiratory and systemic immune responses reveals myeloid cell-driven lung inflammation in severe COVID-19. Immunity 2021;

16. Combes AJ, Courau T, Kuhn NF, et al. Global absence and targeting of protective immune states in severe COVID-19. Nature 2021; 591:124-130.

17. Weinreich DM, Sivapalasingam S, Norton T, et al. REGN-COV2, a Neutralizing Antibody Cocktail, in Outpatients with Covid-19. N Engl J Med 2021; 384:238-251.

18. Chen P, Nirula A, Heller B, et al. SARS-CoV-2 Neutralizing Antibody LY-CoV555 in Outpatients with Covid-19. N Engl J Med 2021; 384:229-237.

19. Gottlieb RL, Nirula A, Chen P, et al. Effect of Bamlanivimab as Monotherapy or in Combination With Etesevimab on Viral Load in Patients With Mild to Moderate COVID-19: A Randomized Clinical Trial. JAMA 2021; 325:632-644.

20. Ruan Q, Yang K, Wang W, Jiang L, Song J. Clinical predictors of mortality due to COVID-19 based on an analysis of data of 150 patients from Wuhan, China. Intensive Care Med 2020; $46: 846-848$.

21. Zhou F, Yu T, Du R, et al. Clinical course and risk factors for mortality of adult inpatients with COVID-19 in Wuhan, China: a retrospective cohort study. Lancet 2020; 395:1054-1062. 
Table 1. Baseline characteristics of patients and clinical outcome.

\begin{tabular}{|c|c|c|c|c|c|}
\hline \multirow[b]{2}{*}{ Characteristic } & \multicolumn{3}{|c|}{$\mathrm{XAV}-19(\mathrm{n}=12)$} & \multirow[t]{2}{*}{ Placebo $(n=5)$} & \multirow[t]{2}{*}{ Total $(n=17)$} \\
\hline & $\begin{array}{c}0.5 \mathrm{mg} / \mathrm{kg} \\
\text { D1-D5 } \\
(\mathrm{n}=6)\end{array}$ & $\begin{array}{c}2 \mathrm{mg} / \mathrm{kg} \\
\mathrm{D} 1-\mathrm{D} 5 \\
(\mathrm{n}=1)\end{array}$ & $\begin{array}{c}2 \mathrm{mg} / \mathrm{kg} \\
\text { D1 } \\
(\mathrm{n}=5)\end{array}$ & & \\
\hline Age, years, median (IQR) & $68(49 \cdot 8 ; 77 \cdot 3)$ & 75 & $74(68 ; 76)$ & $63(51 ; 71)$ & $71(51 ; 75)$ \\
\hline BMI, kg/m², median (IQR) & $25 \cdot 1(23 \cdot 6 ; 29 \cdot 8)$ & $39 \cdot 2$ & $27 \cdot 4(27 \cdot 4 ; 28 \cdot 4)$ & $29 \cdot 3(26 \cdot 1 ; 29 \cdot 8)$ & $27 \cdot 4(25 \cdot 3 ; 31 \cdot 2)$ \\
\hline \multicolumn{6}{|l|}{ Chronic underlying disease, $n(\%)$} \\
\hline Asthma & $2(33 \cdot 3)$ & 0 & 0 & $1(20)$ & $3(17 \cdot 6)$ \\
\hline Diabetes & 0 & 0 & $1(20)$ & $1(20)$ & $2(11 \cdot 8)$ \\
\hline High blood pressure & $4(66 \cdot 7)$ & 1 & $2(40)$ & $1(20)$ & $8(47 \cdot 1)$ \\
\hline Obesity & $1(16 \cdot 7)$ & 0 & $1(20)$ & $1(20)$ & $3(17 \cdot 6)$ \\
\hline Solid organ transplant & $1(16 \cdot 7)$ & 0 & 0 & 0 & $1(5 \cdot 9)$ \\
\hline Solid tumor & $1(16 \cdot 7)$ & 0 & $1(20)$ & 0 & $2(11 \cdot 8)$ \\
\hline
\end{tabular}




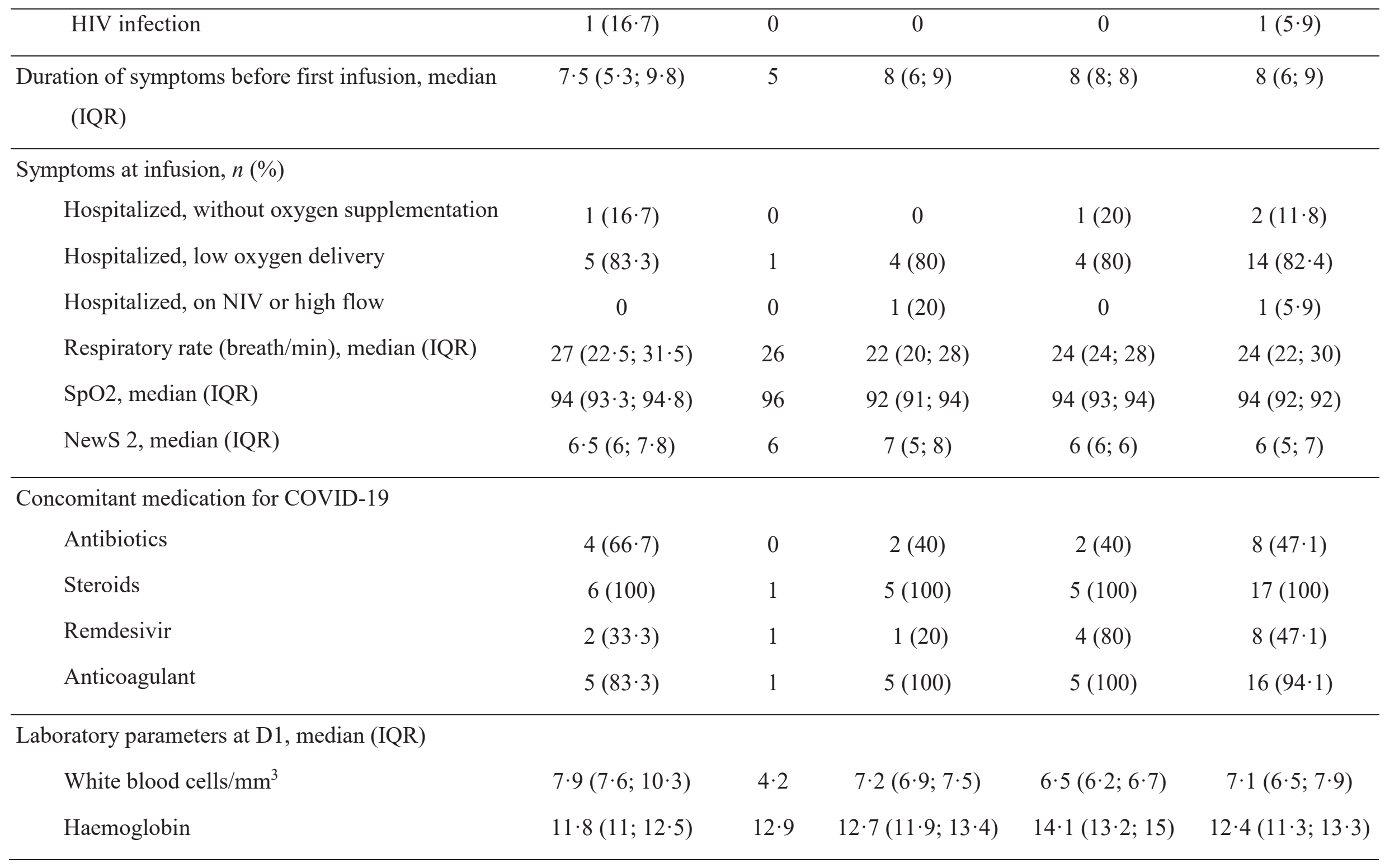




\begin{tabular}{|c|c|c|c|c|c|}
\hline Platelets $/ \mathrm{mm}^{3}$ & $314(238 \cdot 8 ; 407 \cdot 5)$ & 163 & $257(237 ; 276)$ & $244.5(191 ; 297)$ & $261(172 ; 350)$ \\
\hline Creatinine $^{\mathrm{a}}$ & $85(76 \cdot 3 ; 92 \cdot 8)$ & 86 & $65 \cdot 5(64 ; 67)$ & $76(71 \cdot 5 ; 80 \cdot 5)$ & $84(67 ; 86)$ \\
\hline ICU admission, $n(\%)$ & 0 & 0 & $2(40)$ & $1(20)$ & $3(17 \cdot 6)$ \\
\hline Hospital length of stay, days, median (IQR) & $5 \cdot 5(5 ; 11 \cdot 3)$ & 10 & $11(7 ; 12)$ & $7(7 ; 12)$ & $7(6 ; 12)$ \\
\hline 60-day mortality, $n(\%)$ & $1(14 \cdot 3)$ & 0 & 0 & 0 & $1(5 \cdot 6)$ \\
\hline
\end{tabular}

${ }^{a}$ missing data: $0.5 \mathrm{mg} / \mathrm{kg}$ group at day 1 and $5(\mathrm{n}=2), 2 \mathrm{mg} / \mathrm{kg}$ group at D1 $(\mathrm{n}=3)$, placebo group $(\mathrm{n}=3)$. 
Table 2. XAV-19 pharmacokinetic-parameter estimates according to dose and schedule of administration.

\begin{tabular}{|c|c|c|c|c|}
\hline \multirow{4}{*}{ Variable } & \multicolumn{3}{|c|}{$\mathrm{XAV}-19(\mathrm{n}=12)$} & \multirow[t]{4}{*}{$P$ value } \\
\hline & $0.5 \mathrm{mg} / \mathrm{kg}$ & $2 \mathrm{mg} / \mathrm{kg}$ & $2 \mathrm{mg} / \mathrm{kg}$ & \\
\hline & D1 and D5 & D1 and D5 & D1 & \\
\hline & $(n=6)$ & $(\mathrm{n}=1)$ & $(\mathrm{n}=5)$ & \\
\hline $\begin{array}{l}\text { Concentration post day } 1 \text { infusion, } \\
\text { median (min-max) }\end{array}$ & $6 \cdot 90(3 \cdot 29-10 \cdot 9)$ & \multicolumn{2}{|c|}{$47 \cdot 35(29 \cdot 10-55) *$} & 0.0022 \\
\hline $\begin{array}{l}\text { Serum concentration at D8 } \\
(\mu \mathrm{g} / \mathrm{mL}), \text { median (min-max) }\end{array}$ & $6 \cdot 4(2 \cdot 8-11 \cdot 9)$ & $47 \cdot 2$ & $20 \cdot 3(12 \cdot 0-22 \cdot 7)$ & 0.012 \\
\hline $\begin{array}{l}\mathrm{AUC}_{0-\infty}(\mu \mathrm{g} / \mathrm{mL} \times \mathrm{h}), \text { median } \\
(\text { min-max) }\end{array}$ & $4,564(987-7,832)$ & 2,5638 & $12 \cdot 519(7 \cdot 515-14 \cdot 314)$ & 0.018 \\
\hline $\mathrm{C}_{\max }(\mu \mathrm{g} / \mathrm{mL})$, median $(\min -\max )$ & $9 \cdot 1(5 \cdot 2-18 \cdot 1)$ & $71 \cdot 5$ & $50 \cdot 4(29 \cdot 1-55 \cdot 0)$ & 0.012 \\
\hline $\mathrm{T}_{\max }$ & Day 5 post dose & Day 5 post dose & Day 1 post dose & \\
\hline $\mathrm{t}_{1 / 2}$ (days), median (min-max) & $14 \cdot 5(0 \cdot 7-19 \cdot 4)$ & $11 \cdot 88$ & $11 \cdot 4(5.5-13 \cdot 9)$ & 0.211 \\
\hline
\end{tabular}

* values for all Day 1 post-infusion measures at the dose of $2 \mathrm{mg} / \mathrm{kg}(\mathrm{n}=6)$.

AUC, Area under the serum concentration-time Curve; Cmax, maximum serum concentration; $T_{\max }$, time that a drug is present at the maximum concentration in serum; $\mathrm{t}_{1 / 2}$, half-life. 
Table 3. Adverse events (safety analysis population) over 29 days, numbers of patients (\%) with at least 1 event in class.

\begin{tabular}{|c|c|c|c|c|}
\hline \multirow{3}{*}{ Adverse event } & \multicolumn{3}{|c|}{$\mathrm{XAV}-19(\mathrm{n}=12)$} & \multirow[t]{3}{*}{ Placebo $(\mathrm{N}=5)$} \\
\hline & $\begin{array}{c}0.5 \mathrm{mg} / \mathrm{kg} \\
\text { D1 and D5 } \\
\quad(\mathrm{n}=7)\end{array}$ & $\begin{array}{c}2 \mathrm{mg} / \mathrm{kg} \\
\text { D1 and D5 } \\
\quad(\mathrm{n}=1)\end{array}$ & $\begin{array}{c}2 \mathrm{mg} / \mathrm{kg} \\
\text { D1 } \\
(\mathrm{n}=5)\end{array}$ & \\
\hline & \multicolumn{3}{|c|}{ Number of patients (percent) } & \\
\hline \multicolumn{5}{|l|}{ Adverse events } \\
\hline Any (per patient), Mean (SD) & $3.7(2.7)$ & 5 & $3(2.6)$ & $5.6(4)$ \\
\hline Grade 1 or 2 & $7(100)$ & $1(100)$ & $4(80)$ & $5(100)$ \\
\hline Grade 3 or 4 & $2(28.6)$ & 0 & $2(40)$ & $3(60)$ \\
\hline Adverse events related to study drug & 1 & 0 & 0 & 1 \\
\hline \multicolumn{5}{|l|}{ Number of patients (\%) with $\geq 1$ adverse events by class according } \\
\hline \multicolumn{5}{|l|}{ to MedDRA (System Organ Class) } \\
\hline Blood and lymphatic system disorders & $3(42.9)$ & 0 & 0 & $1(20)$ \\
\hline Cardiac disorders & 0 & $1(100)$ & 0 & 0 \\
\hline Gastrointestinal disorders & $1(14.3)$ & 0 & 0 & $2(40)$ \\
\hline General disorders and administration site conditions & $1(14.3)$ & $1(100)$ & $1(20)$ & $3(60)$ \\
\hline
\end{tabular}




\begin{tabular}{lcccc}
\hline Hepatobiliary disorders & $1(14.3)$ & $1(100)$ & $2(40)$ & $3(60)$ \\
Infections and infestations & $3(42.9)$ & 0 & 0 & 0 \\
Injury, poisoning and procedural complications & $1(14.3)$ & 0 & 0 & 0 \\
Musculoskeletal and connective tissue disorders & $2(28.6)$ & 0 & 0 & $1(20)$ \\
Neurological/ psychiatric system disorders & $1(14.3)$ & 0 & $1(20)$ & 0 \\
Renal and urinary disorders & $4(57.1)$ & 0 & $3(60)$ & $3(60)$ \\
Respiratory, thoracic and mediastinal disorders & $1(14.3)$ & $1(100)$ & 0 & $2(40)$ \\
Skin and subcutaneous tissue disorders & $1(14.3)$ & 0 & & 0
\end{tabular}


medRxiv preprint doi: https://doi.org/10.1101/2021.04.15.21255549; this version posted April 20, 2021. The copyright holder for this preprint (which was not certified by peer review) is the author/funder, who has granted medRxiv a license to display the preprint in perpetuity.

All rights reserved. No reuse allowed without permission.

\section{FIGURES}

Figure 1. Relationship between AUC0- $\infty$ and cumulative administered dose of XAV-19.

Figure 2. Time course of XAV-19 mean (+/- standard deviation) serum concentration in the groups of patients. $\mathrm{D}=$ day.

Figure 3. Clinical Status According to 7-Category WHO Ordinal Scale between screening (day 0) and last-follow-up (day 60) in placebo $(\mathrm{n}=5)$ and XAV-19 $(\mathrm{n}=12)$ groups.

Figure 4. Nasopharyngeal viral load over time in placebo $(n=4)$ and XAV-19 2mg/kg $(n=4)$ groups. 
medRxiv preprint doi: https://doi.org/10.1101/2021.04.15.21255549; this version posted April 20, 2021. The copyright holder for this preprint (which was not certified by peer review) is the author/funder, who has granted medRxiv a license to display the preprint in perpetuity.

All rights reserved. No reuse allowed without permission.

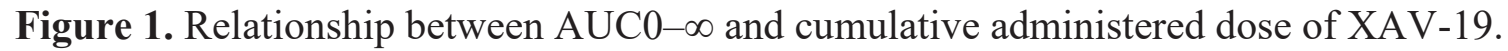

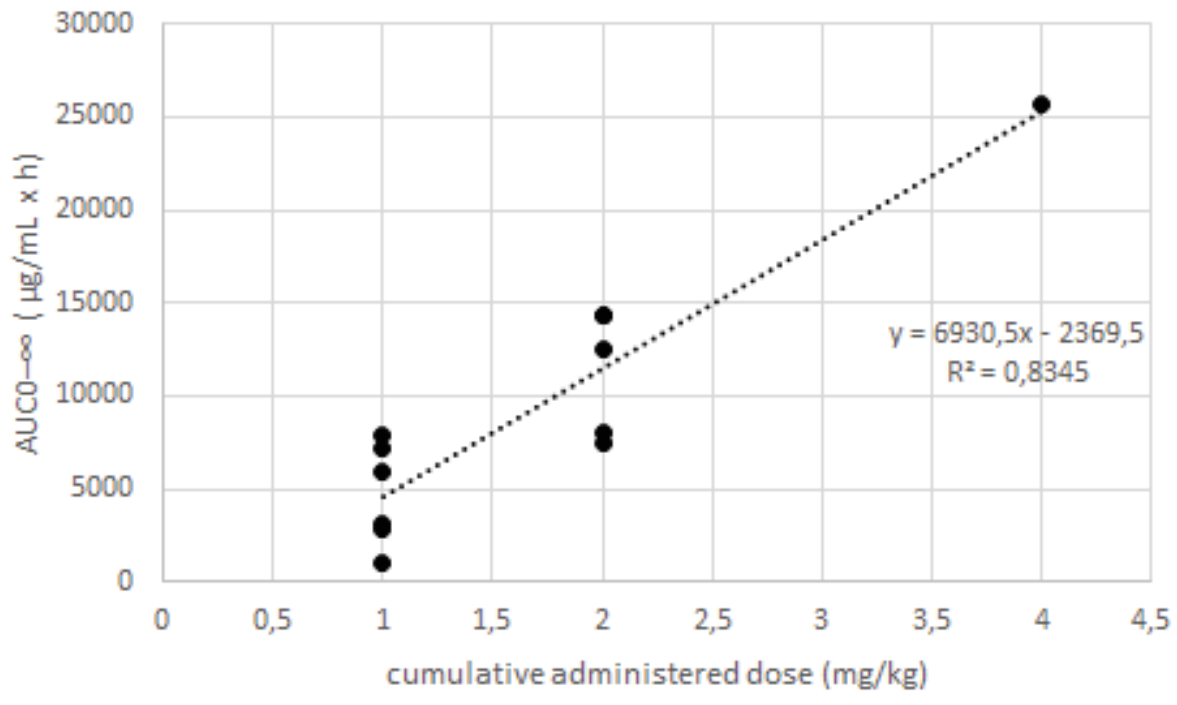


medRxiv preprint doi: https://doi.org/10.1101/2021.04.15.21255549; this version posted April 20, 2021. The copyright holder for this preprint (which was not certified by peer review) is the author/funder, who has granted medRxiv a license to display the preprint in perpetuity.

All rights reserved. No reuse allowed without permission.

Figure 2. Time course of XAV-19 mean (+/- standard deviation) serum concentration in the groups of patients. $\mathrm{D}=$ day.

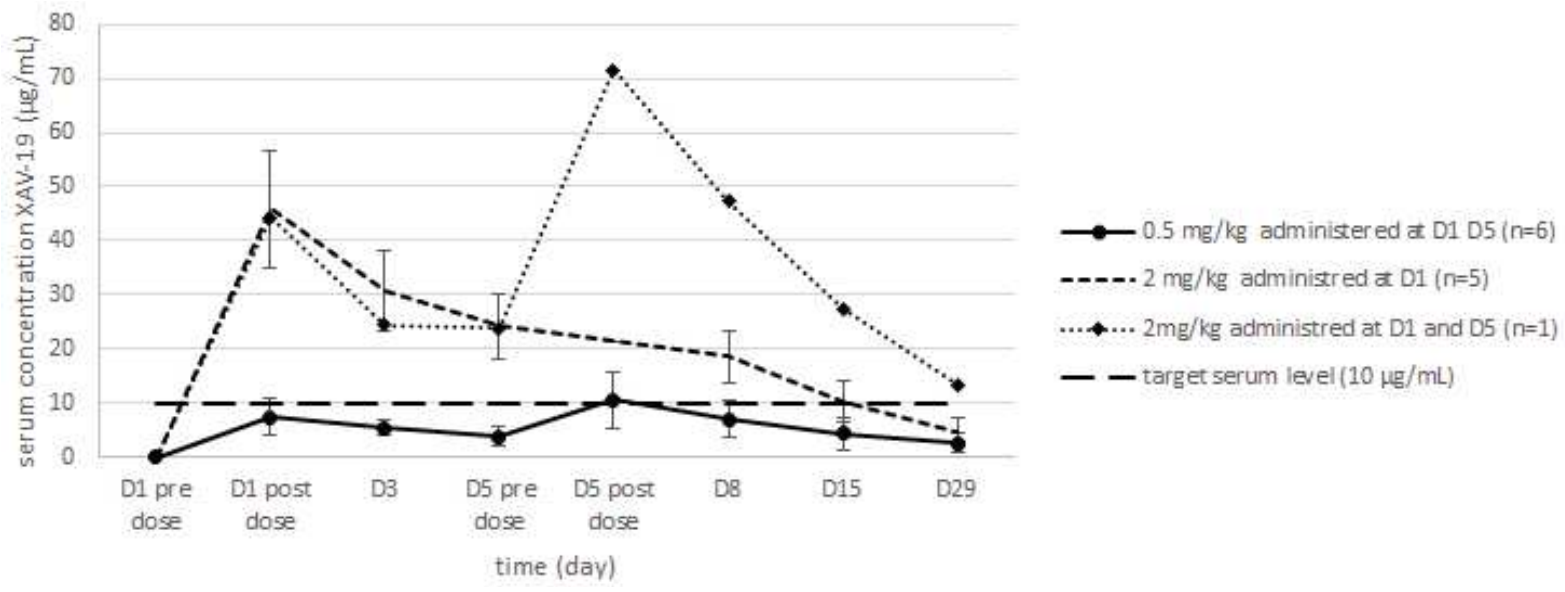

$\mathrm{D}=$ day 
medRxiv preprint doi: https://doi.org/10.1101/2021.04.15.21255549; this version posted April 20, 2021 . The copyright holder for this preprint (which was not certified by peer review) is the author/funder, who has granted medRxiv a license to display the preprint in perpetuity. All rights reserved. No reuse allowed without permission.

Figure 3. Clinical Status According to 7-Category WHO Ordinal Scale between screening (day 0) and last-follow-up (day 60) in placebo $(\mathrm{n}=5)$ and XAV-19 $(\mathrm{n}=12)$ groups.

Placebo $(n=5)$

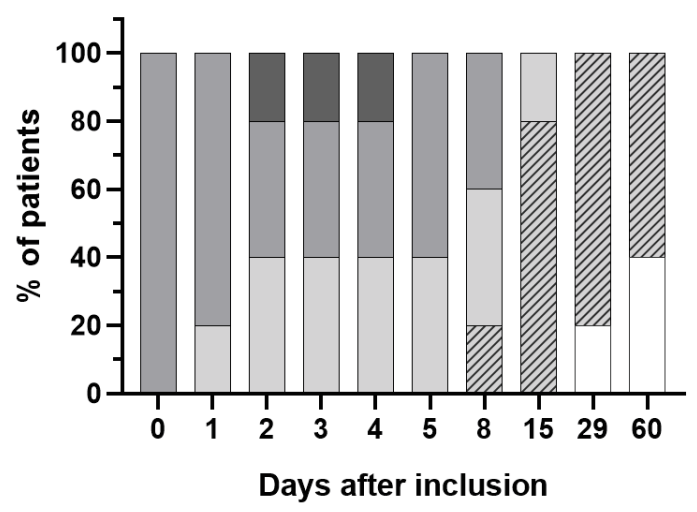

$\operatorname{XAV-19}(n=12)$

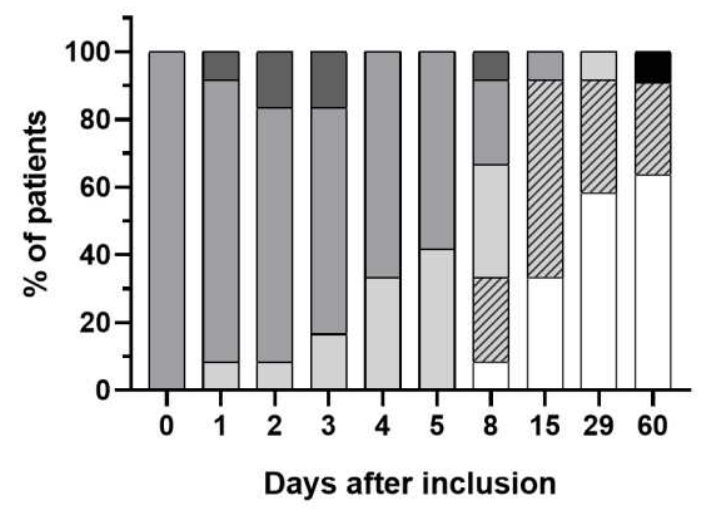

7- Death

$\square$ 6- Hospitalized on invasive ventil.

5- Hospitalized, on non-invasive ventilation or high flow oxygen devices

$\square$ 4- hospitalized, requiring supplemental oxygen

$\square$ 3- Hospitalized, not requiring supplemental $\mathrm{O} 2$

2- Not hospitalized, limitations on activities

$\square$ 1- Not hospitalized, no limitation of activities 
medRxiv preprint doi: https://doi.org/10.1101/2021.04.15.21255549; this version posted April 20, 2021. The copyright holder for this preprint (which was not certified by peer review) is the author/funder, who has granted medRxiv a license to display the preprint in perpetuity.

Figure 4. Nasopharyngeal viral load over time in placebo $(n=5)$ and XAV-19 $2 \mathrm{mg} / \mathrm{kg}(\mathrm{n}=4)$ groups.

\section{Placebo}

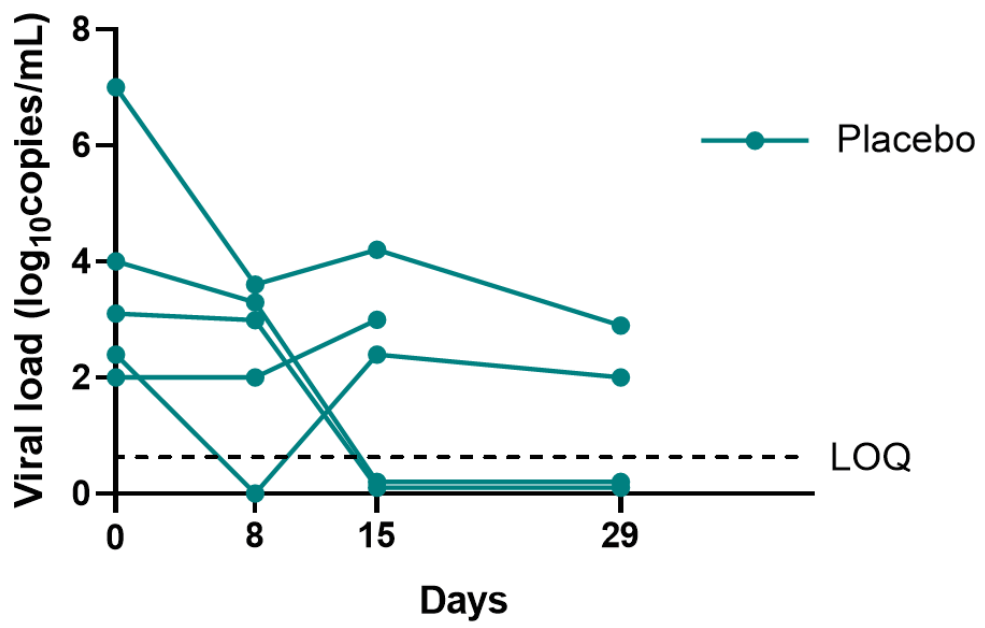

XAV-19 2mg/kg

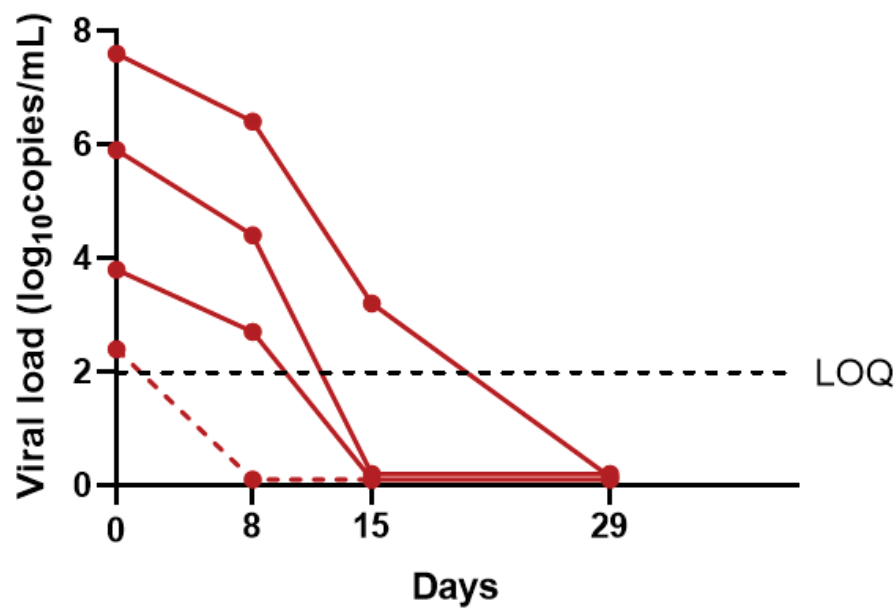

$\begin{array}{ll}\longrightarrow & \text { XAV-19 2mg/Kg D1 } \\ --- & \text { XAV-19 2mg/Kg D1and D5 }\end{array}$

$\mathrm{D}=$ day, $\mathrm{LOD}=$ limit of detection $\left(2.2 \log _{10}\right.$ copies $\left./ \mathrm{mL}\right), 0=$ no signal detected 


\section{Supplemental material}

Supplemental Figure 1. Flow diagram

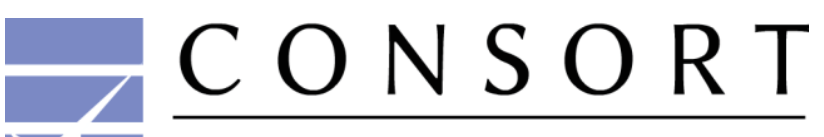

TRANSPARENT REPORTING of TRIALS

CONSORT 2010, Flow Diagram

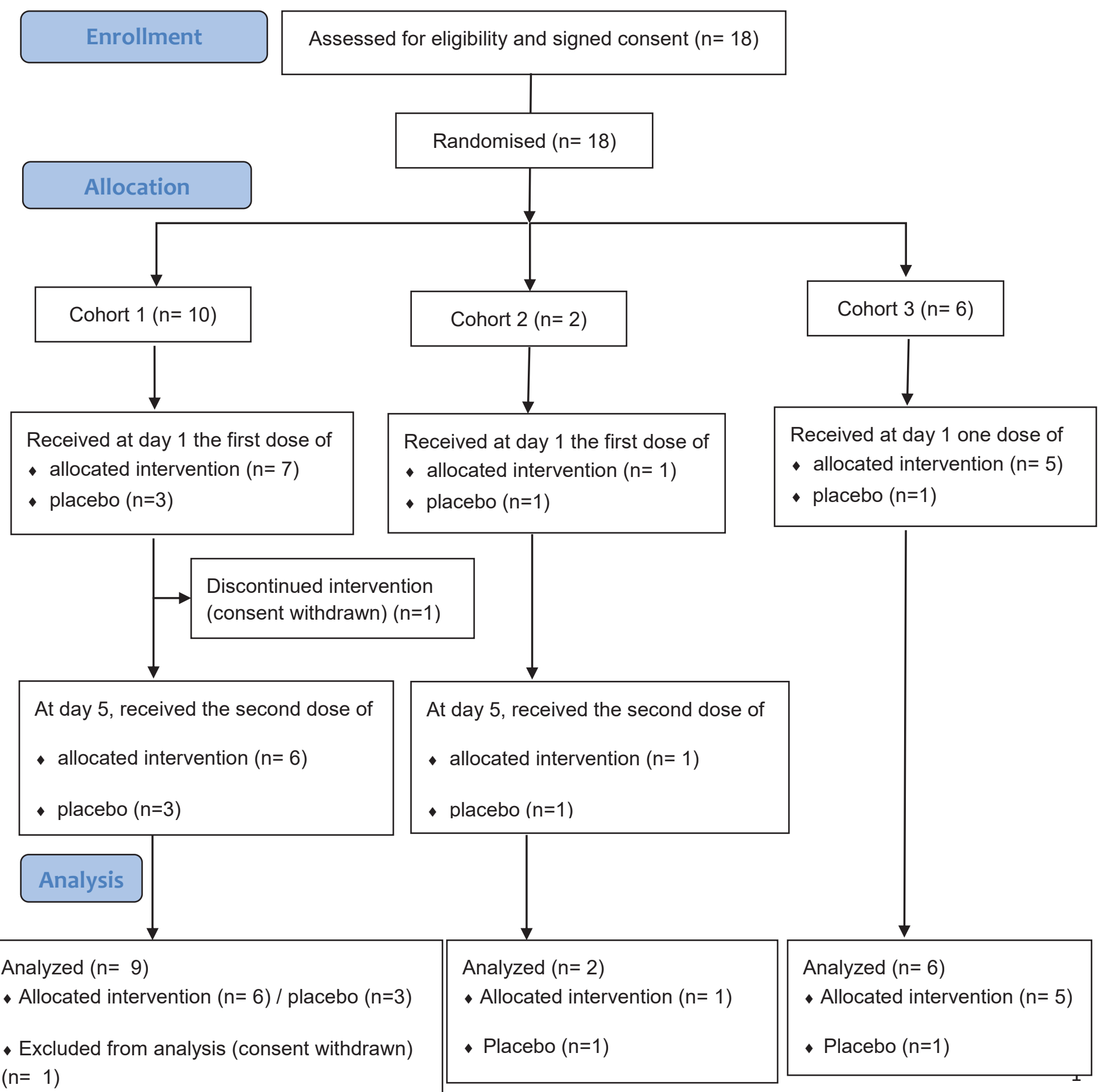


Supplemental Table 1. Adverse events by system organ class and grade occurring in either treatment group to day 29 (safety population).

\begin{tabular}{|c|c|c|c|c|c|}
\hline & $\begin{array}{c}\text { XAV-19 } \\
0.5 \mathrm{mg} \\
\text { D1-D5 } \\
\mathrm{N}=7\end{array}$ & $\begin{array}{c}\text { XAV-19 } \\
2 \mathrm{mg} / \mathrm{kg} \\
\mathrm{D} 1-\mathrm{D} 5 \\
\mathrm{~N}=1\end{array}$ & $\begin{array}{c}\text { XAV-19 } \\
2 \mathrm{mg} / \mathrm{kg} \\
\mathrm{D} 1 \\
\mathrm{~N}=5\end{array}$ & $\begin{array}{c}\text { Placebo } \\
N=5\end{array}$ & Total \\
\hline CARDIAC DISORDERS & & 1 & & & 1 \\
\hline Grade 2 & & 1 & & & 1 \\
\hline BLOOD AND LYMPHATIC SYSTEM DISORDERS & 3 & & & 2 & 5 \\
\hline Grade 1 & 1 & & & 2 & 3 \\
\hline Grade 2 & 2 & & & & 2 \\
\hline GASTROINTESTINAL DISORDERS & 2 & & & 3 & 5 \\
\hline Grade 1 & 1 & & & 3 & 4 \\
\hline Grade 2 & 1 & & & & 1 \\
\hline GENERAL DISORDERS AND ADMINISTRATION SITE CONDITIONS & 1 & 1 & 1 & 3 & 6 \\
\hline Grade 1 & & 1 & 1 & 2 & 4 \\
\hline Grade 2 & 1 & & & & 1 \\
\hline Grade 3 & & & & 1 & 1 \\
\hline HEPATOBILIARY DISORDERS & 3 & 2 & 4 & 4 & 13 \\
\hline Grade 1 & 1 & 2 & 1 & 4 & 8 \\
\hline Grade 2 & 1 & & 2 & & 3 \\
\hline Grade 3 & 1 & & 1 & & 2 \\
\hline INFECTIONS AND INFESTATIONS & 3 & & & & 3 \\
\hline Grade 1 & 2 & & & & 2 \\
\hline Grade 2 & 1 & & & & 1 \\
\hline INJURY, POISONING AND PROCEDURAL COMPLICATIONS & 1 & & & & 1 \\
\hline Grade 1 & 1 & & & & 1 \\
\hline MUSCULOSKELETAL AND CONNECTIVE TISSUE DISORDERS & 2 & & & 2 & 4 \\
\hline Grade 1 & 1 & & & & 1 \\
\hline Grade 2 & 1 & & & 2 & 3 \\
\hline NERVOUS / PSYCHIATRIC SYSTEM DISORDERS & 2 & & 2 & 5 & 9 \\
\hline Grade 1 & & & 1 & 4 & 5 \\
\hline Grade 2 & 2 & & 1 & 1 & 4 \\
\hline RENAL AND URINARY DISORDERS & 5 & & 2 & & 7 \\
\hline Grade 1 & 4 & & 2 & & 6 \\
\hline Grade 2 & 1 & & & & 1 \\
\hline RESPIRATORY, THORACIC AND MEDIASTINAL DISORDERS & 1 & 1 & 6 & 5 & 13 \\
\hline Grade 1 & & 1 & 4 & 2 & 7 \\
\hline Grade 2 & & & & 1 & 1 \\
\hline Grade 3 & 1 & & & 1 & 2 \\
\hline Grade 4 & & & 2 & 1 & 3 \\
\hline SKIN AND SUBCUTANEOUS TISSUE DISORDERS & 1 & & & 4 & 5 \\
\hline Grade 1 & 1 & & & 3 & 4 \\
\hline Grade 2 & & & & 1 & 1 \\
\hline Total & 24 & 5 & 15 & 28 & 72 \\
\hline
\end{tabular}

Data are shown as number of events.

System organ class and preferred terms were determined according to the Medical Dictionary for Regulatory Activities, version 23.0. 
Supplemental Table 2. Adverse events by system organ class and preferred term occurring in either treatment group to day 29 (safety population).

\begin{tabular}{|c|c|c|c|c|c|}
\hline & $\begin{array}{c}\text { XAV-19 } \\
0.5 \mathrm{mg} \\
\text { D1-D5 } \\
\mathrm{N}=7\end{array}$ & $\begin{array}{c}\text { XAV-19 } \\
2 \mathrm{mg} / \mathrm{kg} \\
\mathrm{D} 1-\mathrm{D} 5 \\
\mathrm{~N}=1\end{array}$ & $\begin{array}{c}\mathrm{XAV}-19 \\
2 \mathrm{mg} / \mathrm{kg} \\
\mathrm{D} 1 \\
\mathrm{~N}=5\end{array}$ & $\begin{array}{c}\text { Placebo } \\
\mathrm{N}=5\end{array}$ & Total \\
\hline Cardiac disorders & & 1 & & & 1 \\
\hline Heart sounds abnormal & & 1 & & & 1 \\
\hline Blood and lymphatic system disorders & 3 & & & 2 & 5 \\
\hline Iron deficiency anaemia & 1 & & & & 1 \\
\hline Lymphadenopathy & & & & 1 & 1 \\
\hline Lymphangitis & & & & 1 & 1 \\
\hline Platelet count increased & 1 & & & & 1 \\
\hline White blood cell count increased & 1 & & & & 1 \\
\hline Gastrointestinal disorders & 2 & & & 3 & 5 \\
\hline Diarrhoea & & & & 2 & 2 \\
\hline Gastritis & 1 & & & & 1 \\
\hline Oesophageal pain & & & & 1 & 1 \\
\hline Subileus & 1 & & & & 1 \\
\hline General disorders and administration site conditions & 1 & 1 & 1 & 3 & 6 \\
\hline Asthenia & & & & 2 & 2 \\
\hline Chills & & & 1 & & 1 \\
\hline Hyperthermia & 1 & & & & 1 \\
\hline Interleukin level increased & & 1 & & & 1 \\
\hline Pyrexia & & & & 1 & 1 \\
\hline Hepatobiliary disorders & 3 & 2 & 4 & 4 & 13 \\
\hline Alanine aminotransferase increased & 1 & 1 & 1 & 2 & 5 \\
\hline Aspartate aminotransferase increased & 1 & 1 & 1 & 1 & 4 \\
\hline Gamma-glutamyltransferase increased & 1 & & 1 & & 2 \\
\hline Hepatocellular injury & & & 1 & 1 & 2 \\
\hline Infections and infestations & 3 & & & & 3 \\
\hline Pharyngitis & 1 & & & & 1 \\
\hline Pneumonia pseudomonal & 1 & & & & 1 \\
\hline Urinary tract infection & 1 & & & & 1 \\
\hline Injury, poisoning and procedural complications & 1 & & & & 1 \\
\hline Fall & 1 & & & & 1 \\
\hline Musculoskeletal and connective tissue disorders & 2 & & & 2 & 4 \\
\hline Arthralgia & & & & 1 & 1 \\
\hline Blood creatine phosphokinase decreased & 1 & & & & 1 \\
\hline Gouty arthritis & 1 & & & & 1 \\
\hline Myalgia & & & & 1 & 1 \\
\hline Nervous / psychiatric system disorders & 2 & & 2 & 5 & 9 \\
\hline Ageusia & & & & 1 & 1 \\
\hline Anxiety & 1 & & & & 1 \\
\hline Aphasia & 1 & & & & 1 \\
\hline Headache & & & 1 & 1 & 2 \\
\hline Hyposmia & & & & 1 & 1 \\
\hline Insomnia & & & 1 & 1 & 2 \\
\hline Memory impairment & & & & 1 & 1 \\
\hline Renal and urinary disorders & 5 & & 2 & & 7 \\
\hline Blood bicarbonate decreased & 1 & & & & 1 \\
\hline Blood creatinine increased & 1 & & & & 1 \\
\hline Blood phosphorus decreased & 1 & & 1 & & 2 \\
\hline Hypokalaemia & & & 1 & & 1 \\
\hline Pollakiuria & 1 & & & & 1 \\
\hline
\end{tabular}




\begin{tabular}{|c|c|c|c|c|c|}
\hline Renal failure & 1 & & & & 1 \\
\hline Respiratory, thoracic and mediastinal disorders & 1 & 1 & 6 & 5 & 13 \\
\hline Chest pain & & & 1 & & 1 \\
\hline Cough & & & 1 & 2 & 3 \\
\hline Dyspnoea & & & & 1 & 1 \\
\hline Hypoxia & & & 1 & & 1 \\
\hline Respiratory distress & & & 2 & 1 & 3 \\
\hline Respiratory failure & 1 & & & & 1 \\
\hline Rhinorrhoea & & & & 1 & 1 \\
\hline Tachypnoea & & 1 & 1 & & 2 \\
\hline Skin and subcutaneous tissue disorders & 1 & & & 4 & 5 \\
\hline Alopecia & & & & 1 & 1 \\
\hline Ecchymosis & 1 & & & & 1 \\
\hline Mucosal inflammation & & & & 1 & 1 \\
\hline Pruritus & & & & 1 & 1 \\
\hline Rosacea & & & & 1 & 1 \\
\hline Total & 24 & 5 & 15 & 28 & 72 \\
\hline
\end{tabular}

Data are shown as number of events.

System organ class and preferred terms were determined according to the Medical Dictionary for Regulatory Activities, version 23.0 . 